ORIGINAL ARTICLE

\title{
Analysis and characterization of cultivable extremophilic hydrolytic bacterial community in heavy-metal- contaminated soils from the Atacama Desert and their biotechnological potentials
}

\author{
M.L. Moreno ${ }^{1}$, F. Piubeli², M.R.L. Bonfá2, M.T. García ${ }^{1}$, L.R. Durrant ${ }^{2}$ and E. Mellado ${ }^{1}$ \\ 1 Department of Microbiology and Parasitology, Faculty of Pharmacy, University of Sevilla, Sevilla, Spain \\ 2 Departamento de Ciência de Alimentos-FEA Universidade Estadual de Campinas-UNICAMP, Campinas, SP Brazil
}

Keywords

Atacama Desert, halophiles, halotolerants, heavy-metal-contaminated soils, hydrolytic extremophilic bacteria.

\section{Correspondence \\ Encarnación Mellado, Department of Microbi- ology and Parasitology, Faculty of Pharmacy, University of Sevilla, C/Profesor García González, 2, 41012 Sevilla, Spain. E-mail: emellado@us.es}

2012/0577: received 30 March 2012, revised 12 June 2012 and accepted 16 June 2012

doi:10.1111/j.1365-2672.2012.05366.x

\begin{abstract}
Aims: To isolate and characterize the cultivable community of hydrolase producers (amylase, protease, lipase, DNase, xylanase and pullulanase) inhabiting heavy-metal-contaminated soils in extreme conditions from the Atacama Desert. Methods and Results: A total of 25 bacterial strains showing hydrolytic activities have been selected including halotolerants, extremely halotolerants and moderate halophiles. Most hydrolase producers were assigned to the family Bacillaceae, belonging to the genera Bacillus (nine strains), Halobacillus (seven strains) and Thalassobacillus (five strains) and four isolates were related to members of the families Pseudomonadaceae, Halomonadaceae and Staphylococcaceae. The selected strains were then characterized for their tolerance pattern to six heavy metals, measured as minimal inhibitory concentrations (MICs).

Conclusions: The diversity found in the cultivable bacterial community analysed is more limited than that detected in other ecological studies owing to the restrictive conditions used in the screening. The dominant bacteria were Firmicutes and particularly, species related to the genus Bacillus.

Significance and Impact of the Study: This study is focused on the characterization of extremophilic hydrolytic bacteria, providing candidates as a source of novel enzymes with biotechnological applications.
\end{abstract}

\section{Introduction}

The Atacama Desert in northern Chile is a coastal desert usually described as one of the driest deserts on Earth, with a surface that has been minimally disturbed by natural erosion for millions of years (McKay et al. 2003; Hartley et al. 2005). This region includes arid and semi arid environments with many different saline deposits. In these saline deposits, evaporative basins called saltflats can be found (Chong 1984) containing a high percentage of salts from the leaching of volcanic rocks.

Until recently, regions of the Atacama Desert were considered the dry limit of photosynthetic activity and primary production (Warren-Rhodes et al. 2006), with extremely low levels of cultivable organisms and oxidized organic species detected in the soils (Navarro-González et al. 2003). In spite of the extreme conditions of this desert habitat, a broad spectrum of halotolerant and halophilic bacteria and archaeas have been found in saltflats and hypersaline lakes in the area (Demergasso et al. 2004; Wierzchos et al. 2006; Connon et al. 2007; De los Ríos et al. 2010).

Different classification schemes have been designed to define the relationships of micro-organisms with salt. The most widely accepted classification is based on the optimal salt concentration for their growth (Kushner and Kamekura 1988).

The halotolerance of many enzymes derived from halotolerant and halophilic micro-organisms can be exploited wherever enzymatic transformations are 
required to function under extreme physical and chemical conditions (Oren 2002a; Setati 2010). Hydrolases produced by halophiles have quite diverse potential usage in different areas (food industry, feed additive, biomedical sciences and chemical industries) (Rao et al. 1998; Kulkarni et al. 1999; Niehaus et al. 1999) and several halophilic enzymes have been tested for their potential biotechnological applications, including amylases, nucleases and proteases (Oren 2002b).

The Atacama Desert has increased its levels of heavy metals owing to natural and industrial processes (Salamanca et al. 2000). Cadmium, copper and zinc are among those heavy metals that are being released in the environment. Although some heavy metals constitute essential trace elements, most can be, at high concentrations, toxic to organisms from all branches of life, including bacteria (Nies 1999). However, some bacteria have adapted their physiology to tolerate the presence of metals or can even use them to grow. Owing to their exceptional characteristics, salt tolerant bacteria adapted to live in hostile environments may exhibit the potential to remove heavy metals from contaminated environments (Mishra et al. 2009; Zhuang et al. 2010). However, very little information is available on the heavy-metal tolerance of bacteria in hypersaline environments, with the exception of a few studies of metal-resistant halophilic bacteria isolated from different habitats such as the Maruit Lake, Egypt (Osman et al. 2010) or the Dead Sea Shore, Jordan (Amoozegar et al. 2005; Massadeh et al. 2005).

Therefore, in the present work, we studied the cultivable diversity of hydrolytic enzyme producers in a bacterial community from saline soils of the Atacama Desert. Furthermore, these strains were evaluated for their biotechnological potentials in terms of hydrolytic enzyme activity and heavy-metal tolerance.

\section{Materials and methods}

\section{Description of sampling sites and collection}

Samples were collected in September 2010 from two different points in the Atacama Desert region (Chile), designated as follows: Atacama Salar (AS) (in the Pre-Andean Depression) (latitude $23^{\circ} 300^{\prime} \mathrm{S}$, longitude $68^{\circ} 150^{\prime} \mathrm{W}$ ) and Death Valley (DV), (latitude $22^{\circ} 555^{\prime} \mathrm{S}$, longitude $68^{\circ} 120^{\prime}$ $\mathrm{W})$, both closely located to copper and lead-zinc mine tailings. The AS is the largest saltflat in Chile and is located in the east region of the Antofagasta district of Chile. The Salar is $100 \mathrm{~km}$ long and $80 \mathrm{~km}$ wide, and the salts have an athalassohaline origin. The DV, also known as the Mars Valley, located in the Salt Mountain range, is very close to San Pedro de Atacama, standing out owing to its sand dunes of up to $150 \mathrm{~m}$ in height. The average annual precipitation in AS and DV is $<1$ and $4 \mathrm{~mm}$, respectively, with a high UV index. At each site, we collected four samples, including pieces of halite crusts broken off AS and surface soils $(0-20 \mathrm{~mm})$ from DV. Samples were taken in sterile plastic containers and stored in an icebox until further processed. Concentrations of $\mathrm{Na}, \mathrm{Ca}, \mathrm{K}, \mathrm{Fe}, \mathrm{Mg}, \mathrm{B}, \mathrm{As}, \mathrm{Mn}, \mathrm{Cu}$ and $\mathrm{Zn}$ were determined via ICP-OES (Inductively coupled plasma-optical emission spectrometry) using an Iris Advantage spectrometer (Thermo Jarrel Ash Corporation, MA, Franklin, USA). Calcium carbonate $\left(\mathrm{CaCO}_{3}\right)$ was determined using an automated continuous flow analyser (Bran + Luebbe III, Germany). Soil pH and electrical conductivity (EC) were determined in a $1: 5$ soil/water extract. An electronic thermometer (Orion model 290) was used to measure temperature. Soil samples were air-dried, crushed and sieved through a $2-\mathrm{mm}$ sieve. Total organic carbon (TOC) was analysed by dichromate oxidation and titration with ferrous ammonium sulphate (Walkley and Black 1934).

\section{Isolation of hydrolytic producers}

The isolation of micro-organisms producing hydrolytic enzymes was performed by diluting collected samples from the Atacama Desert (from $10^{-1}$ to $10^{-3}$ ) in saline solution $(0.9 \% \mathrm{NaCl}, \mathrm{w} / \mathrm{v})$ and inoculating $100 \mu \mathrm{l}$ of the dilution into saline medium (BS-10 medium) with $10 \%$ $(\mathrm{w} / \mathrm{v})$ total salts and $1 \%(\mathrm{w} / \mathrm{v})$ yeast extract and substrates to assay for amylase, protease, lipase, DNase, xylanase and pullulanase activities. The salts solution (SW) composition contained in the $\mathrm{BS}$ medium was as follows $\left(\mathrm{g} \mathrm{l}^{-1}\right): \mathrm{NaCl}(234), \mathrm{MgSO}_{4} \cdot 7 \mathrm{H}_{2} \mathrm{O}(61), \mathrm{MgCl}_{2} \cdot 6 \mathrm{H}_{2} \mathrm{O}$ (39), $\mathrm{KCl}(6), \mathrm{CaCl}_{2}(1), \mathrm{NaBr}(0 \cdot 7)$ and $\mathrm{NaCO}_{3} \mathrm{H}(0 \cdot 2)$. When necessary, different concentrations of salts solution were added to BS medium as indicated. Solid media were prepared by adding $2 \%(\mathrm{w} / \mathrm{v})$ bacteriological-agar (Difco Laboratories, Detroit, MI). The plates were incubated at $37^{\circ} \mathrm{C}$ in aerobic conditions.

Amylase activity was determined using solid BS-10 medium supplemented with $0 \cdot 5 \%(\mathrm{w} / \mathrm{v})$ soluble starch. After incubation for 15 days, the plates were flooded with $0.3 \%$ $(\mathrm{w} / \mathrm{v}) \mathrm{I}_{2}-0 \cdot 6 \%(\mathrm{v} / \mathrm{v})$ KI solution: a clear zone around the colonies indicated hydrolysis of starch (Cowan and Steel 1982). Protease activity was screened qualitatively in the saline BS-10 medium amended with $2 \%(\mathrm{w} / \mathrm{v})$ skim milk. Zones of precipitation of paracasein around the colonies appearing over the next 15 days were taken as evidence of proteolytic activity (Cowan and Steel 1982). Lipase activity of the strains was detected by screening for zones of hydrolysis around colonies growing on solid BS-10 medium, containing $1 \%(\mathrm{w} / \mathrm{v})$ tributyrin after incubation for 15 days (Mourey and Kilbertus 1976). The presence of 
DNase activity on plates was determined on DNase test agar (BBL) containing $10 \%(\mathrm{w} / \mathrm{v})$ total salts. After incubation for 15 days, the plates were flooded with $1 \mathrm{~N} \mathrm{HCl}$ solution. Clear halos around the colonies indicated DNase activity (Jeffries et al. 1957). Xylanase and pullulanase activities were tested in BS-10 medium with the chromogenic substrates $(0 \cdot 1 \%$, w/v) AZCL-xylan and AZCL-pullulan (Megazyme, Bray, Ireland). After this time, xylanolytic and pullulolytic activities were detected showing clearing zones around the colonies.

The positive hydrolytic isolates (64 strains) were replicated in the solid BS-10 medium containing the corresponding substrates and were tested again for the hydrolytic activities. A Gram stain test of the colonies was performed before proceeding to further studies.

\section{Salt requirement}

The growth response to $\mathrm{NaCl}$ of the isolates was examined in BS medium containing $0,1,3,5,7 \cdot 5,10$, $12 \cdot 5,15,17 \cdot 5,20,25$ and $30 \%(\mathrm{w} / \mathrm{v}) \mathrm{NaCl}$ and incubated at $37^{\circ} \mathrm{C}$ on a rotary shaker (New Brunswick Scientific Co, NJ, USA) operating at $200 \mathrm{rev} \mathrm{min}^{-1}$. Growth curves of the isolates were obtained by monitoring the culture absorbance at $600 \mathrm{~nm}$ using a Perkin-Elmer spectrophotometer at different incubation times. For this purpose, 250 -ml flasks containing $50 \mathrm{ml}$ of saline medium were each inoculated with $100 \mu \mathrm{l}$ of a stationary-phase culture. Samples $(500 \mu \mathrm{l})$ were taken at $6,12,18,24,40$ and $48 \mathrm{~h}$ to monitor the culture absorbance.

\section{Heavy-metal tolerance testing}

For the determination of tolerance to heavy metals, solid BS medium containing the optimal concentration of $\mathrm{NaCl}$ for each isolate was used. The range of concentrations for the heavy metals tested (cadmium, zinc, nickel, iron, copper and cobalt) ranged from 0.5 to $4 \mathrm{mmol}^{-1}$ $\left(0 \cdot 5,1,2,3\right.$ and $\left.4 \mathrm{mmol} \mathrm{l}^{-1}\right)$. Controls consisting of media without metals and inoculated with the test microorganisms were carried out in all experiments. After incubation at $37^{\circ} \mathrm{C}$ for $2-3$ days, the results were interpreted. The lowest concentration of metal that completely prevented growth was named the minimum inhibitory concentration (MIC). The MICs for all strains were determined by triplicate.

\section{Isolation of genomic DNA and amplification of $16 \mathrm{~S}$ rRNA gene}

DNA of isolated strains was extracted and precipitated following the CTAB protocol for bacterial genomic DNA preparations (Wilson 1987). The $16 \mathrm{~S}$ ribosomal RNA gene was amplified by polymerase chain reaction (PCR) using total DNA as the template and universal primers designed for Bacteria. The 16S rRNA PCR amplification was performed using the forward primer 16F27 (5'-AGAGTTTGATCMTGGCTCAG-3') and the reverse primer 16R1488 (5'-CGGTTACCTTGTTAGGACTTCACC-3') (Lane 1991). The following programme was used for amplification: one cycle of $95^{\circ} \mathrm{C}$ for $5 \mathrm{~min}, 25$ cycles of $94^{\circ} \mathrm{C}$ for $1 \mathrm{~min}, 50^{\circ} \mathrm{C}$ for $1 \mathrm{~min}$, and $72^{\circ} \mathrm{C}$ for $2 \mathrm{~min}$, and then an extension step for $10 \mathrm{~min}$ at $72^{\circ} \mathrm{C}$. The amplified DNA fragments were analysed on $1 \%(\mathrm{w} / \mathrm{v})$ agarose gels stained with ethidium bromide and photographed with UV illumination.

Amplified rDNA restriction analysis (ARDRA) and 16S rRNA sequence analysis

The PCR products of the 16S rRNA gene were digested with $1 \mathrm{U}$ of the restriction endonucleases $A l u \mathrm{I}$ and $H$ haI (Fermentas MBI, Vilnius, Lithuania) at $37^{\circ} \mathrm{C}$ for $2 \mathrm{~h}$. The digestion products were detected by gel electrophoresis in $2 \%$ agarose gels and visualized after staining with ethidium bromide. ARDRA profiles were analysed, and representative unique clones were selected for nucleotide sequence determination. The amplified DNA fragments were sequenced using an automated DNA sequencer model 9700 (Applied Biosystems, Foster City, CA). The 16S rRNA gene sequences obtained were compared to the sequences in the GenBank data bases and aligned with the most similar sequences available to construct the phylogenetic trees using the ARB software package (Ludwig and Strunk 1996). Evolutionary distance matrices were calculated using the neighbour-joining algorithm (Ludwig et al. 1998). Phylogenetic trees using different methods (distance matrix, maximum parsimony and maximum likelihood) were constructed and compared to elucidate the confidence of local topologies.

\section{Nucleotide sequence accession numbers}

The nucleotide sequences reported in this work have been deposited in the EMBL Nucleotide Sequence Database under accession numbers HE586566 to HE586590.

\section{Results}

\section{Physicochemical analysis of the collected samples}

Both sampling areas selected in the Atacama Desert are characterized by a high solar radiation and large temperature fluctuations between day and night.

Table 1 shows the physicochemical characterization of the collected samples. The main ionic composition in 
Table 1 Chemical and physical properties of collected samples from the Atacama Desert region

\begin{tabular}{|c|c|c|}
\hline \multirow[b]{2}{*}{ Parameter } & \multicolumn{2}{|l|}{ Isolation site } \\
\hline & Atacama Salar (AS) & Death Valley (DV) \\
\hline $\mathrm{Na}^{+}\left(\mathrm{mg} \mathrm{l}^{-1}\right)^{\star}$ & 1648 & 222 \\
\hline $\mathrm{Ca}^{2+}\left(\mathrm{mg} \mathrm{I}^{-1}\right)^{\star}$ & 184 & 233 \\
\hline $\mathrm{K}^{+}\left(\mathrm{mg} \mathrm{I}^{-1}\right)^{\star}$ & 163 & 214 \\
\hline $\mathrm{Fe}\left(\mathrm{mg} \mathrm{l}^{-1}\right)^{*}$ & $29 \cdot 6$ & 195 \\
\hline $\mathrm{Mg}^{2+}\left(\mathrm{mg} \mathrm{I}^{-1}\right)^{\star}$ & 196 & 59.43 \\
\hline$B\left(\left.m g\right|^{-1}\right)^{\star}$ & 51.91 & 0.311 \\
\hline As $\left(\mathrm{mg} \mathrm{l}^{-1}\right)^{*}$ & 1.194 & 0.276 \\
\hline $\mathrm{Mn}\left(\mathrm{mg} \mathrm{I}^{-1}\right)^{*}$ & $35 \cdot 84$ & 0.05 \\
\hline $\mathrm{Cu}\left(\mathrm{mg} \mathrm{l}^{-1}\right)^{*}$ & $3 \cdot 13$ & 0.017 \\
\hline $\mathrm{Zn}\left(\mathrm{mg} \mathrm{I}^{-1}\right)^{*}$ & 3.972 & $<0.001$ \\
\hline $\mathrm{pH}$ & $8.68 \pm 0.064$ & $9.54 \pm 0.11$ \\
\hline $\mathrm{EC}\left(\mathrm{mS} \mathrm{cm} \mathrm{cm}^{-1}\right)$ & $127 \pm 11 \cdot 3$ & $0.633 \pm 0.0133$ \\
\hline TOC $\left(\mathrm{mg} \mathrm{kg}^{-1}\right)$ & $<0.1$ & $0.91 \pm 0.01$ \\
\hline Moisture (\%) & $7 \cdot 30$ & 3.50 \\
\hline
\end{tabular}

Mean values \pm standard deviation $(n=3)$ of Moisture content, Electrical Conductivity (EC), pH and Total Organic Carbon (TOC) in samples. *Average values of the collected samples from two sampling sites.

both sampling sites was different. Samples from AS presented higher salt concentrations, particularly $\mathrm{Na}^{+}$ followed by $\mathrm{Mg}^{+}, \mathrm{Ca}^{+}, \mathrm{K}^{+}$and $\mathrm{Mn}^{+}$ions. The analysis of samples from DV revealed a similar concentration of $\mathrm{Ca}^{+}$and $\mathrm{K}^{+}$ions but significantly higher concentrations of $\mathrm{Fe}$. The $\mathrm{pH}$ values differed in AS and DV although in both cases alkaline values were obtained. The TOC content was lower in AS $\left(<0 \cdot 1 \mathrm{mg} \mathrm{kg}^{-1}\right)$ than DV $\left(0.91 \mathrm{mg} \mathrm{kg}^{-1}\right)$. Sodium concentration and electrical conductivity displayed the largest difference along our study samples.

\section{Screening and selection of extremophilic} micro-organisms producing hydrolytic enzymes

A total of 64 colonies showing hydrolytic activity were chosen for analysis. The 16S rRNA genes of these isolated strains were amplified. Restriction analysis of the amplified $16 \mathrm{~S}$ rRNA genes using the restriction endonucleases AluI and Hha Indicated the presence of different groups of restriction patterns. Twenty-five unique isolates representing the major cluster groups were selected for further analysis.

The most frequent hydrolytic activity detected in our study was DNase (20\% of the hydrolytic population), followed by amylase and lipase activities. From the 25 selected isolates by full 16S rRNA gene sequencing, 21 of them showed DNase activity (16 isolates from AS and five isolates from DV), 20 showed amylase activity (16 isolates from AS and four isolates from DV) and 19 showed lipase activity (14 isolates from AS and five isolates from DV). Concerning the pullulanase producers (17 strains), this group represents the $17 \%$ of the hydrolytic population (15 isolates from AS and two isolates from DV). In the analysed community, the proteolytic producers constituted $15 \%$ of the isolates showing hydrolytic activities (10 isolates from AS and five isolates from DV). Xylanases were the least hydrolases represented (eight isolates from AS and three isolates from DV) (Table 2). Combined activities were detected in most of the isolates. Eleven strains presented five hydrolytic activities, nine strains presented four hydrolytic activities, two strains presented three hydrolytic activities and three strains presented two hydrolytic activities. No strains with all of the hydrolytic activities tested have been found in this study.

\section{Determination of the saline requirement}

The assay performed to determine the salt growth profile for the 25 isolates (Table S1, supporting information) revealed that most of them grew in the $\mathrm{NaCl}$ range of $2-25 \%(w / v)$ and showed optimal growth at $7 \cdot 5 \%(\mathrm{w} / \mathrm{v})$ $\mathrm{NaCl}$. Seven strains showed optimal growth without $\mathrm{NaCl}$, although they were able to grow in presence of $\mathrm{NaCl}$ and other salts. Only two strains showed optimal growth without $\mathrm{NaCl}$ but were able to grow at high concentrations of salts (up to $17 \cdot 5 \% \mathrm{NaCl}$ ).

\section{Phylogenetic analysis of the isolates}

Comparative sequence analyses of the $16 \mathrm{~S}$ rRNA genes from the 25 isolates were performed (Table 2). The majority of the isolates were Gram-positive bacteria assigned to the family Bacillaceae and included in the genera Bacillus (nine strains), Halobacillus (seven strains) and Thalassobacillus (five strains). Two Gram-negative isolates were assigned as members of the Pseudomonadaceae and Halomonadaceae families, included in the genera Pseudomonas and Halomonas, respectively. Only two species were detected in the study belonging to the genus Salinicoccus within the Staphylococcaceae family. Essentially, similar results were obtained using different methods to construct the phylogenetic trees. Therefore, we only include the neighbour-joining tree (Fig. 1).

Among the hydrolytic community analysed, the strains isolated from the AS samples, containing higher salt concentrations were assigned to five different genera. However, the strains isolated from DV samples, with moderate salinity and organic matter content, but presenting alkaline $\mathrm{pH}$, were all identified as species of the genus Bacillus.

Table 2 summarizes the hydrolytic activities of the isolates. The DNase producers represented the group with 
Table 2 Bacterial diversity based on the 16S rRNA gene and hydrolytic activities of the strains isolated from the desert soils samples

\begin{tabular}{|c|c|c|c|c|c|c|c|c|c|}
\hline \multirow[b]{2}{*}{ Strain } & \multirow[b]{2}{*}{ Closest relative } & \multirow[b]{2}{*}{$\%$ Similarity } & \multirow[b]{2}{*}{ Accession no. } & \multicolumn{6}{|c|}{ Hydrolytic activity } \\
\hline & & & & Protease & Lipase & Amylase & DNase & Pullulanase & Xylanase \\
\hline DV1 & Bacillus seohaeanensis & 99 & AY667495 & + & - & - & + & - & - \\
\hline DV2 & & & & + & + & - & + & - & - \\
\hline DV3 & & & & - & + & - & + & - & - \\
\hline DV4 & Bacillus subtilis subsp. inaquosorum & 99 & EU138467 & + & + & + & - & + & + \\
\hline AS1 & & & & + & + & - & + & - & + \\
\hline DV5 & Bacillus stratosphericus & 99 & AJ831841 & - & - & + & + & + & - \\
\hline DV6 & Bacillus oceanisediminis & 99 & GQ292772 & + & + & + & + & - & + \\
\hline AS2 & Bacillus mojavensis & 99 & EU138460 & - & + & - & + & - & - \\
\hline DV7 & Bacillus licheniformis & 97 & AB301007 & + & + & + & - & - & + \\
\hline AS3 & Pseudomonas halophila & 99 & AB021383 & + & + & + & + & - & - \\
\hline AS4 & Halobacillus hunanensis & 98 & FJ425898 & + & + & + & + & + & - \\
\hline AS5 & & & & + & + & + & + & + & - \\
\hline AS6 & Halobacillus profundi & 98-99 & AB189298 & - & - & + & + & + & + \\
\hline AS7 & & & & - & - & + & + & + & + \\
\hline AS8 & & & & - & + & + & + & + & + \\
\hline AS9 & & & & - & - & + & + & + & + \\
\hline AS10 & & & & - & - & + & + & + & + \\
\hline AS11 & Thalassobacillus devorans & $98-99$ & AJ717299 & - & + & + & + & + & - \\
\hline AS12 & & & & - & + & + & + & + & - \\
\hline AS13 & & & & + & + & + & + & + & - \\
\hline AS14 & & & & + & + & + & + & + & - \\
\hline AS15 & & & & + & + & + & + & + & - \\
\hline AS16 & Halomonas organivorans & 98 & NR_029029 & + & + & + & + & + & - \\
\hline AS17 & Salinicoccus roseus & 98 & NR_026311 & + & + & + & - & + & + \\
\hline AS18 & & & & + & + & + & - & + & + \\
\hline
\end{tabular}

the highest number of strains (21 strains), including isolates with high affinity to the genera Bacillus, Halobacillus, Thalassobacillus and closely related to the species Pseudomonas halophila and Halomonas organivorans. Among the amylolytic strains (20 strains), most of them were related to moderate halophiles included in the genera Halobacillus, Thalassobacillus, Salinicoccus, Halomonas and Pseudomonas. Only four strains were closely related to halotolerant members of the genus Bacillus. Isolates producing lipolytic enzymes (19 strains) showed high affinity to species related to the genera Bacillus, Pseudomonas, Halobacillus, Thalassobacillus, Halomonas and Salinicoccus. The presence of lipolytic activity was an important characteristic to differentiate isolates assigned to the same species (Bacillus seohaeanensis, Halobacillus hunanensis and Halobacillus profundi). A total of 17 strains showed pullulanase activity. In comparison with other activities, an absence of pullulanase activity was found among the Bacillus strains. Concerning the isolates producing proteolytic enzymes (15 strains), we detected strains related to the genera Bacillus, Pseudomonas and Halomonas and closely related to Thalassobacillus devorans, H. hunanensis and Salinicoccus roseus. Only 11 strains showed xylanase activity and were included in the genera Halobacillus, Bacillus and Salinicoccus.

\section{Response to heavy metals}

The heavy-metal tolerance levels of the isolates from the Atacama Desert to six heavy metals, expressed as MICs, are shown in Table 3. There is not a specific and accepted metal concentration that could be used as a standard to define universally metal resistance. Moreover, metal salts and microbial media components can interact in ways which make data interpretation difficult. Thus, in general, for the metal tested, those strains which were not inhibited by $4.0 \mathrm{mmol} \mathrm{l}^{-1}$ of the metal ions could be considered tolerant to these metals. The strains that were not inhibited by $3.0 \mathrm{mmol}^{-1}$ could be considered moderately tolerant to these metals.

On the basis of the MICs, the highest toxicities were found with cadmium and zinc. Only one strain related to Thalasobacillus devorans (AS14) was cadmium tolerant. Three strains, related to the genera Bacillus (DV4 and DV5) and Thalassobacillus (AS12) could be considered as moderately tolerant to cadmium. Only two strains related to the genus Bacillus (DV1 and DV6) were considered tolerant to zinc and three strains (DV3, DV4 and DV5) as moderately zinc tolerant. In contrast, $\mathrm{Ni}$ was shown to be the least toxic metal for the isolates, with $56 \%$ of the tested isolates demonstrating tolerance to this metal. The 




Figure 1 Phylogenetic neighbour-joining tree based on the analysis of 16S rRNA gene sequences, showing the diversity of micro-organisms able to produce hydrolytic enzymes. The isolates described in the present study are shown in bold. Isolates from Atacama Salar are indicated as AS, and isolates from Death Valley are indicated as DV. 16S rRNA gene sequences from the isolates correspond to sequences of 1400 bp. Bootstrap values ( $>50 \%$, based on 1000 replications) are shown at branch points. Bar represents a $2 \%$ sequence difference.

susceptibility levels of the isolated strains to $\mathrm{Fe}$ and $\mathrm{Cu}$ was more heterogeneous, nine strains $(36 \%$ of the total isolates) were tolerant to iron and one strain was moderately tolerant. Seven strains (DV2, DV4, DV5, AS7, AS9, AS13 and AS15) were tolerant to copper and two strains (AS11 and AS14) were moderately tolerant to this metal. Species related to H. hunanensis (AS4 and AS5) were the most sensitive to all the metal tested. In contrast, the strains related to Bacillus subtilis (DV4) and Bacillus stratosphericus (DV5) were the most tolerant to the heavy metals tested, showing higher tolerance to four different metal ions $(\mathrm{Fe}, \mathrm{Co}, \mathrm{Ni}$ and $\mathrm{Cu}$ ) and moderate tolerance to $\mathrm{Cd}$ and $\mathrm{Zn}$.

\section{Discussion}

Few environmental studies have focused on the study of the bacterial community inhabiting saline and hypersaline habitats in the Atacama Desert (Demergasso et al. 2004; Connon et al. 2007; Lester et al. 2007; Mishra et al. 2009; De los Ríos et al. 2010) and, in particular, to our knowledge, no screening programmes have been designed to select extremophilic micro-organisms with the ability to produce enzymes that hydrolyse polymeric compounds, although the hydrolases play a key role in the geochemical cycling of nutrients as the hydrolysis of high molecular weight biopolymers constitutes an initial step 
Table 3 Minimal inhibitory concentrations (MICs) of the metal ions tested against the bacterial hydrolase producers

\begin{tabular}{lllllll}
\hline & \multicolumn{3}{l}{ MIC $\left(\mathrm{mmol} \mathrm{I}^{-1}\right)$} & & & \\
\cline { 2 - 7 } Strain & Cd & Zn & Ni & Fe & Cu & Co \\
\hline DV1 & 0.5 & 4 & 4 & 2 & 0.5 & 0.5 \\
DV2 & 0.5 & 1 & 4 & 4 & 4 & 0.5 \\
DV3 & 0.5 & 3 & 4 & 2 & 1 & 0.5 \\
DV4 & 3 & 3 & 4 & 4 & 4 & 4 \\
AS1 & 0.5 & 0.5 & 4 & 2 & 2 & 1 \\
DV5 & 3 & 3 & 4 & 4 & 4 & 4 \\
DV6 & 0.5 & 4 & 4 & 4 & 1 & 1 \\
AS2 & 0.5 & 0.5 & 4 & 2 & 1 & 1 \\
DV7 & 0.5 & 0.5 & 4 & 3 & 1 & 4 \\
AS3 & 0.5 & 0.5 & 1 & 0.5 & 0.5 & 0.5 \\
AS4 & 0.5 & 0.5 & 0.5 & 0.5 & 0.5 & 0.5 \\
AS5 & 0.5 & 0.5 & 0.5 & 0.5 & 0.5 & 0.5 \\
AS6 & 0.5 & 0.5 & 1 & 0.5 & 0.5 & 4 \\
AS7 & 0.5 & 0.5 & 3 & 0.5 & 4 & 4 \\
AS8 & 0.5 & 0.5 & 1 & 4 & 0.5 & 0.5 \\
AS9 & 0.5 & 0.5 & 1 & 0.5 & 4 & 2 \\
AS10 & 0.5 & 0.5 & 3 & 1 & 0.5 & 2 \\
AS11 & 0.5 & 0.5 & 4 & 4 & 3 & 1 \\
AS12 & 3 & 0.5 & 1 & 4 & 0.5 & 2 \\
AS13 & 0.5 & 0.5 & 1 & 0.5 & 4 & 2 \\
AS14 & 4 & 0.5 & 4 & 4 & 3 & 2 \\
AS15 & 0.5 & 2 & 2 & 0.5 & 4 & 3 \\
AS16 & 0.5 & 0.5 & 4 & 4 & 2 & 4 \\
AS17 & 0.5 & 1 & 2 & 0.5 & 2 & 1 \\
AS18 & 0.5 & 0.5 & 2 & 0.5 & 2 & 1 \\
\hline
\end{tabular}

in the metabolism of organic compounds in the different ecosystems.

Under the restrictive conditions used in our screening, a total of 64 fresh cultures showing hydrolytic activities were isolated and from them, 25 strains were selected and characterized. Most isolates (16 strains) grow optimally in media containing between 5 and $7 \%(\mathrm{w} / \mathrm{v})$ total salts, being able to grow in most cases up to $25 \%(\mathrm{w} / \mathrm{v})$ salts. Thus, they can be classified as moderate halophiles according to the classification proposed by Kushner and Kamekura (1988). All the moderate halophiles were isolated from the AS. The number of halotolerant isolates was remarkably lower compared with that of moderate halophiles. Representative members of the halotolerant group were detected in both sampling sites, and the two extremely halotolerant strains (DV2 and AS2) were isolated from the Death Valley.

The most frequent hydrolytic activity detected in our study was DNase, followed by amylase and lipase activities. In the analysed community, we also detected pullulanase and protease producers. Xylanases were the least represented hydrolases. Sánchez-Porro et al. (2003) showed the abundance of five hydrolytic enzymes including amylase, protease, lipase, DNase and pullulanase in a community of moderate halophiles isolated from salterns in Spain, and they described amylase producers as the most abundant isolates. Furthermore, Moreno et al. (2009) studied the diversity of extreme halophiles, producing lipase, protease, amylase and nuclease in hypersaline ecosystems in South Spain, concluding that $70 \%$ of total of the hydrolytic isolates were also amylase producers. However, Baati et al. (2010) in the screening performed in salt mines of Sfax (Tunisia) detected a similar percentage of proteases, amylases and DNases producers. Rohban et al. (2009) investigated the ability of halophilic strains isolated from a hypersaline lake in Iran to produce nine different extracellular hydrolases (inulinase, pectinase, cellulase and xylanase). In contrast to our results, the most frequent activity expressed by these isolates was lipase, and the least prevalent activity represented was DNase.

It is interesting to emphasize that combined hydrolytic activity was frequently detected in isolates from both sampled areas, AS and the Death Valley. These results support previous studies in other hypersaline habitats (Sánchez-Porro et al. 2003; Moreno et al. 2009), although the number of strains showing combined hydrolytic activity is higher in the present study.

Based on the comparison of partial sequences of $16 \mathrm{~S}$ rRNA genes, most environmental isolates able to produce hydrolytic enzymes were Gram-positive bacteria, assigned to the family Bacillaceae, comprising species of the genera Bacillus (Cohn 1872), Halobacillus (Spring et al. 1996) and Thalassobacillus (García et al. 2005). Bacillus is well known as an extracellular enzymes producer and many industrial processes use species of this genus for commercial production of enzymes (Schallmey et al. 2004). Only two isolates were related to the Gram-negative bacteria Ps. halophila (Sorokin et al. 2006) and H. organivorans (García et al. 2004). The other characterized isolates were related to S. roseus (Ventosa et al. 1990).

Although no organic matter is detected in the samples obtained from the AS, a broader diversity is found among the isolates if compared to that obtained from the Dead Valley, identifying only hydrolytic producers from the genus Bacillus. Probably, the presence of hydrolases is more significant among the population found in the AS samples to obtain nutrients in an adverse environment.

The cultivable microbial diversity found in this study is more limited than that detected in other ecological studies performed in diverse areas of the Atacama Desert, selecting only strains of the phyla $\gamma$-Proteobacteria (families Halomonadaceae and Pseudomonadaceae) and Firmicutes (families Bacillaceae and Staphylococcaceae). However, this study was carried out under more restrictive conditions. Our results differ from others in the preponderant hydrolytic bacteria. While the overall 
preponderant bacteria in our study were Firmicutes (92\%), $\gamma$ and $\beta$-Proteobacteria were reported as predominant in other studies (Rohban et al. 2009; Baati et al. 2010) in which Firmicutes did not appear or they were a minority.

Several studies have demonstrated that metal toxicity can be heavily influenced by environmental factors such as $\mathrm{pH}$, temperature, soluble organic matter, clay minerals, inorganic anionic and cationic components (Nieto et al. 1989). Responses to the heavy metals tested in this study were very heterogeneous, with at least three different MICs being detected for the different metal ions in species belonging to the same genus (Table 3 ). In fact, four different MICs were found for zinc, copper and cobalt in Bacillus species. This suggests that halotolerant and halophilic bacteria express a very heterogeneous behaviour in connection with their individual natural susceptibility to the six heavy metals tested in the present study. Here, the highest toxicities were found with cadmium and zinc ( $80 \%$ of isolates were sensitive). This might be due to the fact that $\mathrm{Cd}$ is toxic per se and has not been found to be essential for biological functions in bacteria. Only one strain related to $T$. devorans showed high tolerance to cadmium $\left(4.0 \mathrm{mmol} \mathrm{l}^{-1}\right)$. The majority of strains were tolerant to nickel. The prevalence of Ni-resistant isolates has been shown in other saline environments previously described (Gaballa et al. 2003). Species related to $H$. hunanensis were the most sensitive to the heavy metals tested and the strains related to Bacillus subtilis and Bacillus stratosphericus were the most tolerant, showing tolerance to four different metal ions ( $\mathrm{Fe}, \mathrm{Co}, \mathrm{Ni}$ and $\mathrm{Cu}$ ) and moderate tolerance to $\mathrm{Cd}$ and $\mathrm{Zn}$. Bacillus species have been shown to have the ability to accumulate gold, cadmium, chromium, copper, iron and manganese (El-meleigy et al. 2010). In our study, Gram-positive bacteria presented higher tolerance (less growth inhibition) to heavy metals than their Gram-negative counterparts, although Gram-negative bacteria tend to be the predominant prokaryotes in metal-polluted environments, owing to the structure and composition of their cell walls (Duxbury 1986).

In conclusion, in this work, we analysed and characterized the cultivable extremophilic hydrolytic bacterial community inhabiting the saltflats of the Atacama Desert. The isolated strains were evaluated for their biotechnological potentials in terms of hydrolytic enzyme activity and heavy-metal tolerance. We identify two outstanding implications: (i) the discovering of the Atacama Desert as a source for isolation of novel enzymes with biotechnological potential and (ii) development of heavy-metal-tolerant micro-organisms as potential innovative technology for bioremediation operations to remove heavy metal from saline soils.

\section{Acknowledgements}

This work was supported by grants from the Spanish Ministry of Science and Education (CTM 2006-03310) and Junta de Andalucía (P08-RMN-3515). Maria de Lourdes Moreno was supported by a fellowship from the University of Sevilla. Francine Piubeli was supported by a fellowship from Coordination of Improvement of Higher Education Personnel (Capes). We are grateful to Adolfo Crespo for the support in sampling collection.

\section{References}

Amoozegar, M.A., Hamedi, J., Dadashipour, M. and Shariatpanahi, S. (2005). Effect of salinity on the tolerance to toxic metals and oxyanions in native moderately halophilic spore-forming bacilli. World J Microbiol Biotechnol 21, 1237-1243.

Baati, H., Amdouni, R., Gharsallah, N., Sghir, A. and Ammar, E. (2010). Isolation and characterization of moderately halophilic bacteria from tunisian solar saltern. Curr Microbiol 60, 157-161.

Chong, G. (1984). Die Salare in Nordchile - Geologie, Struktur und geochimie. Goetektonische Forschung 67, 1-146.

Cohn, F. (1872). Untersuchungen über Bakterien. Beitr Biol Pflanz Heft 21, 127-224.

Connon, S.A., Lester, E.D., Shafaat, H.S., Obenhuber, D.C. and Ponce, A. (2007) Bacterial diversity in hyperarid Atacama Desert soils. J Geophys Res 112, G04S17.

Cowan, S.T. and Steel, K.J. (1982). Manual para la Identificación de Bacterias de Importancia Médica, 2nd edn. Mexico DF: CECSA.

De los Ríos, A., Valea, S., Ascaso, C., Davila, A., Kastovsky, J., McKay, C.P., Gómez-Silva, B. and Wierzchos, J. (2010)

Comparative analysis of the microbial communities inhabiting halite evaporites of the Atacama Desert. Int Microbiol 13, 79-89.

Demergasso, C., Casamayor, E., Chong, G., Galleguillos, P., Escudero, L. and Pedrós-Alió, C. (2004). Distribution of prokaryotic genetic diversity in athalassohaline lakes of the Atacama desert Northern Chile. FEMS Microbiol Ecol 48, 57-69.

Duxbury, T. (1986). Microbes and heavy metals: an ecological overview. Microbiol Sci 8, 336-339.

El-meleigy, M.A., El-kasaby, A.M. and Osman, N.H. (2010). Microorganisms as a tool in biotechnology of sea water treatment. Aust J Basic Appl Sci 4, 1083-1099.

Gaballa, A., Amer, R., Hussein, H., Moawad, H. and Sabry, S. (2003). Heavy metals resistance pattern of moderately halophytic bacteria. Arab J Biotechnol 6, 267-278.

García, M.T., Mellado, E., Ostos, J.C. and Ventosa, A. (2004). Halomonas organivorans sp. nov., a moderate halophile able to degrade aromatic compounds. Int J Syst Evol Microbiol 54, 1723-1728. 
García, M.T., Gallego, V., Ventosa, A. and Mellado, E. (2005). Thalassobacillus devorans gen. nov., sp. nov., a moderately halophilic, phenol-degrading, Gram-positive bacterium. Int J Syst Evol Microbiol 55, 1789-1795.

Hartley, A.J., Chong, G., Houston, J. and Mather, A.E. (2005). 150 million years of climatic stability: evidence from the Atacama Desert, northern Chile. J Geol Soc 162, 421-424.

Jeffries, C.D., Holtman, D.F. and Guse, D.G. (1957). Rapid method for determining the activity of microorganisms on nucleic acids. J Bacteriol 73, 590-591.

Kulkarni, N., Shendye, A. and Rao, M. (1999). Molecular and biotechnological aspects of xylanases. FEMS Microbiol Rev 23, 11-456.

Kushner, D.J. and Kamekura, M. (1988) Physiology of halophilic bacteria. In Halophilic Bacteria ed. RodríguezValera, F. pp. 109-138. Boca Raton, FL: CRC Press.

Lane, D.J. (1991) 16S/23S rRNA sequencing. In Nucleic Acid Techniques in Bacterial Systematics ed. Stackebrandt, E. and Goodfellow, M. pp. 115-148. Chichester, UK: Wiley.

Lester, E.D., Satomi, M. and Ponce, A. (2007). Microflora of extreme arid Atacama Desert soils. Soil Biol Biochem 39, 704-708.

Ludwig, W. and Strunk, O. (1996) arb: a software environment for sequence data. http://www.mikro. biologie.tu-muenchen.de.

Ludwig, W., Strunk, O., Klugbauer, S., Klugbauer, N., Weizenernegger, M., Neumaier, J., Bachleitner, M. and Schleifer, K.-H. (1998). Bacterial phylogeny based on comparative sequence analysis. Electrophoresis 19, 554-568.

Massadeh, A.M., Al-Momani, F.A. and Haddad, H.I. (2005). Removal of lead and cadmium by halophilic bacteria isolated from the Dead Sea shore, Jordan. Biol Trace Elem Res 108, 259-269.

McKay, C.P., Friedmann, E.I., Gómez-Silva, B., CáceresVillanueva, L., Andersen, D.T. and Landheim, R. (2003). Temperature and moisture conditions in the extreme arid regions of the Atacama Desert: four years of observations including the El Niño of 1997-1998. Astrobiology 3, 393-406.

Mishra, R.R., Dangar, T.K., Rath, B. and Thatoi, H.N. (2009). Characterization and evaluation of stress and heavy metal tolerance of some predominant Gram negative halotolerant bacteria from mangrove soils of Bhitarkanika, Orissa, India. Afr J Biotechnol 8, 2224-2231.

Moreno, M.L., Garcia, M.T., Ventosa, A. and Mellado, E. (2009). Characterization of Salicola sp. IC10, a lipase- and protease producing extreme halophile. FEMS Microbiol Ecol 68, 59-71.

Mourey, A. and Kilbertus, G. (1976). Simple media containing stabilized tributyrin for demonstrating lipolytic bacteria in foods and soils. J Appl Bacteriol 40, 47-51.

Navarro-González, R., Rainey, F.A., Molina, P., Bagaley, D.R., Hollen, B.J., de la Rosa, J., Small, A.M., Quinn, R.C. et al. (2003). Mars-like soils in the atacama, chile, and the dry limit of microbial life. Science 302, 1018-1021.
Niehaus, F., Bertoldo, C., Kahler, M. and Antranikian, G. (1999). Extremophiles as a source of novel enzymes for industrial application. Appl Microbiol Biotechnol 51, 711-729.

Nies, D.H. (1999). Microbial heavy metal resistance. Appl Microbiol Biotechnol 51, 730-750.

Nieto, J.J., Fernandez-Castillo, R., Marquez, M.C., Ventosa, A., Quesada, E. and Ruiz-Berraquero, F. (1989). Survey of metal tolerance in moderately halophilic eubacteria. Appl Environ Microbiol 55, 2385-2390.

Oren, A. (2002a). Diversity of halophilic microorganisms: environments, phylogeny, physiology, and applications. $J$ Ind Microbiol Biotechnol 28, 56-63.

Oren, A. (2002b) Biotechnological Applications and Potentials of Halophilic Microorganisms. In Halophilic Microorganisms and their Environments ed. Oren, A. pp. 357-388. the Netherlands: Springer.

Osman, O., Tanguichi, H., Ikeda, K., Park, P., Tanabe-Hosoi, S. and Nagata, S. (2010). Copper-resistant halophilic bacterium isolated from the polluted Maruit Lake, Egypt. J Appl Microbiol 108, 1459-1470.

Rao, M.B., Tanksale, A.M., Ghatge, M.S. and Deshpande, V.V. (1998). Molecular and Biotechnological aspects of microbial proteases. Microbiol Mol Biol Rev 62, 597-635.

Rohban, R., Amoozegar, M.A. and Ventosa, A. (2009). Screening and isolation of halophilic bacteria producing extracellular hydrolyses from Howz Soltan Lake, Iran. J Ind Microbiol Biotechnol 36, 333-340.

Salamanca, M.A., Camaño, A., Jara, B. and Rodríguez, T. (2000). $\mathrm{Cu}, \mathrm{Pb}$ and $\mathrm{Zn}$ distribution in nearshore water en San Jorge Bay, Northern Chile. Gayana (Concepción) 64, 195-204.

Sánchez-Porro, C., Martín, S., Mellado, E. and Ventosa, A. (2003). Diversity of moderately halophilic bacteria producing extracellular hydrolytic enzymes. J Appl Microbiol 94, 295-300.

Schallmey, M., Singh, A. and Ward, O.P. (2004). Developments in the use of Bacillus species for industrial production. Can J Microbiol 50, 1-17.

Setati, M.E. (2010). Diversity and industrial potential of hydrolase producing halophilic/halotolerant eubacteria. Afr J Biotechnol 9, 1555-1560.

Sorokin, D.Y., Tourova, T.P., Galinski, E.A., Belloch, C. and Tindall, B.J. (2006). Extremely halophilic denitrifying bacteria from hypersaline inland lakes, Halovibrio denitrificans sp. nov. and Halospina denitrificans gen. nov., sp. nov., and evidence that the genus name Halovibrio Fendrich 1989 with the type species Halovibrio variabilis should be associated with DSM 3050. Int J Syst Evol Microbiol 56, 379-388.

Spring, S., Ludwig, W., Marquez, M.C., Ventosa, A. and Schleifer, K.-H. (1996). Halobacillus gen. nov., with description of Halobacillus litoralis sp. nov. and Halobacillus trueperi sp. nov., and transfer of Sporosarcina halophila to Halobacillus halophilus comb. nov. Int J Syst Bacteriol 46, 492-496. 
Ventosa, A., Marquez, M.C., Ruiz-Berraquero, F. and Kocur, M. (1990). Salinicoccus roseus gen. nov., a new moderately halophilic Gram-positive coccus. Syst Appl Microbiol 13, 29-33.

Walkley, A. and Black, I.A. (1934). An examination of the Degtjareff method for determining soil organic matter and a proposed modification of the chromic acid titration method. Soil Sci 37, 29-38.

Warren-Rhodes, K.A., Rhodes, K.L., Pointing, S.B., Ewing, S. A., Lacap, D.C., Gómez-Silva, B., Amundson, R., Friedmann, E.I. et al. (2006). Hypolithic cyanobacteria, dry limit of photosynthesis, and microbial ecology in the hyperarid Atacama Desert. Microb Ecol 52, 389-398.

Wierzchos, J., Ascaso, C. and McKay, C.P. (2006). Endolithic cyanobacteria in halite rocks from the hyperarid core of the Atacama Desert. Astrobiology 6, 415-422.

Wilson, K. (1987) Preparation of genomic DNA from bacteria. In Current Protocols in Molecular Biology ed. Ausubel, F.
M., Brent, R., Kingston, R.E., Moore, D.D., Seidman, J.G., Smith, J.A. and Struhl, K. pp. 2.4.1-2.4.2. New York: John Wiley \& Sons.

Zhuang, X., Han, Z., Bai, Z., Zhuang, G. and Shim, H. (2010). Progress in decontamination by halophilic microorganisms in saline wastewater and soil. Environ Pollut 158, 1119-1126.

\section{Supporting Information}

Additional Supporting Information may be found in the online version of this article:

Table S1. Salt growth range pattern of the isolates.

Please note: Wiley-Blackwell are not responsible for the content or functionality of any supporting materials supplied by the authors. Any queries (other than missing material) should be directed to the corresponding author for the article. 